$$
\begin{aligned}
\frac{\mathrm{V}}{\mathrm{T}} & =\frac{1+2 \mu^{2}}{1+\mu^{2}} \cos \gamma+\frac{\mathrm{e}^{-\mu \alpha}}{\mu}\left(\frac{\mathrm{e}^{-\mu \gamma}-\mathrm{e}^{\mu \gamma}}{2 \gamma}\right) \cos \alpha \\
& +\frac{\mu}{1+\mu^{2}}(\sin \alpha-\mu \cos \alpha) \mathrm{e}^{-\mu \alpha} \cos \gamma \frac{\mathrm{I}}{2 \gamma} \cdots \cdots \\
\frac{\mathrm{H}}{\mathrm{T}} & =-\frac{\mu}{1+\mu^{2}} \cos \gamma-\frac{\mathrm{e}^{-\mu \alpha}}{\mu}\left(\frac{\mathrm{e}^{-\mu \gamma}-\mathrm{e}^{\mu \gamma}}{2 \gamma}\right) \sin \alpha \\
& +\frac{\mu}{1+\mu^{2}}(\mu \sin \alpha+\cos \alpha) \mathrm{e}^{-\mu \alpha} \cos \gamma \frac{\mathrm{I}}{2 \gamma} \cdots \cdots
\end{aligned}
$$

こ\た

$$
\begin{array}{r}
I=-\left(\frac{1}{\mu}+\frac{1}{\mu^{2}}-\frac{2 \gamma^{2}}{\mu}\right)\left(\mathrm{e}^{-\mu \gamma}-\mathrm{e}^{\mu \gamma}\right)-\frac{\gamma}{\mu^{2}}\left(\mathrm{e}^{-\mu \gamma}\right. \\
\left.+\mathrm{e}^{\mu \gamma}\right) \ldots \ldots \ldots \ldots \ldots \ldots \ldots \ldots \ldots \ldots
\end{array}
$$

たバし

$\alpha$ および $\mu$ は諌算I の場合と同じ

$\gamma=$ 糸のバルーニングが作る円錐の半項角

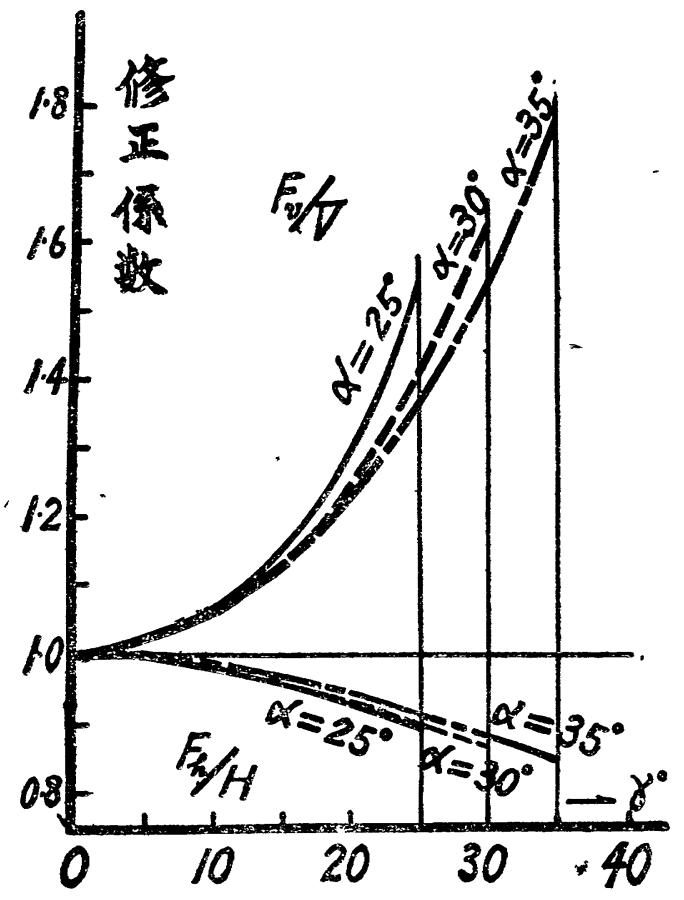

（第 5 図）目盛の読みに対する修正保数 $\mathrm{F}_{\mathrm{v}} / \mathrm{V} \mathrm{F}_{\mathrm{h}} / \mathrm{H}$

\section{5. 修 正 計 算}

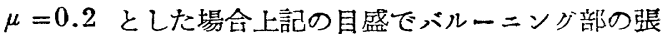
力を測定したとき、これに莱ずべき修正係数を（１）〜 (5) 式より求めれは第5図のよ5になる。

6. 例

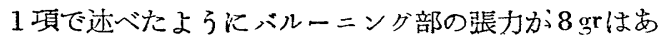
る䇴なのにこのテンソメータを用いると $4 \mathrm{gr}$ となつたわ けを説明する。

この場合のバルーニングのつくる円錐の半項角は 25 度 $(\boldsymbol{\alpha}=27$ 度) であつたから、第 5 図より修正係妍は 1.5 となる。つまり

$$
4 \mathrm{sr} \times 1.5=6 \mathrm{gr}
$$

となる。ところか泤上の計算では刹嫦にスネルワイヤ がらはなれないと仅定したことになつている。糸がスネ ルワイヤからはなれると、さらに修正係数は大きくなる が、今の場合は観察によりたえずスネルワイヤについて いたので修正はこれでよい。

しかしこの $6 \mathrm{gr}$ という值はまだ小さいようである。次 にその理由を述べて結言とする。

\section{7. 結吿}

スネルワイヤをバネ吊りにすると、トラベラの滑走姿 樊が変つたり、念激な張力の変化を緩和したりしてバル 一ニング部の涱力そのものが普通のスネルワイヤを赒い た場合より小さくなるらしい。これはいろいろの比較試 験を行つて明かになつたわけであるかう、結局テンソメー タを作ろろとして、閣題力脑らぬ方向に発展した。.あえ てテンソメータの試作という目的に固悻して云々するな らは将来すし精紡機に㢹性支持のスネルワイヤか使用さ れた場合の张力を測定する方去を゙研究したことになる。

終りにこれは交部省科学試険研究 (ラージパッヶー ジ)【主任研究者庶重呚授〕の一部であつて、本研究グル ープとくに樌田信吉郎君の势力を得たことを記して謝辞 とする。

\title{
杼替裝置の一試 案*
}

\section{1. 緒言}

製作並び取扱の容易な4丁杼替装置を供給する目时 にて、若千の文献及び現用の势裝置を参照して、新に装 置を試作し実用試嗆を行つた。

\section{2. 試作裝置の概要}

第 1 図は裝置の組立の状況、第 2 区はその分解の状況
会員越智隆冬林

である。

機構は、第3 図に㧊いて宩車 1 にて織機のクランク軸 よりタとの咸速にて連動力法えられ、爪車 2 及び 2’は織 機と共に常に回転している。この爪車は回転しなからら軸 に沿つて媔動し得るようになつている。今図の薙勢にて レバ 3 を弓忷は他端の爪 $\mathrm{a}$ は 2 の案内部 $\mathrm{b}$ の内側面を运

* A Trial Production of Shattle Box Change.

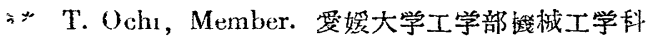




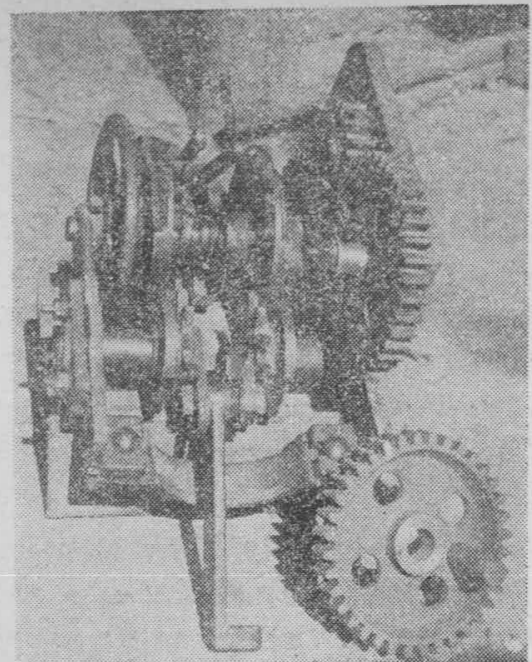

(第1汹) 試作の校惪

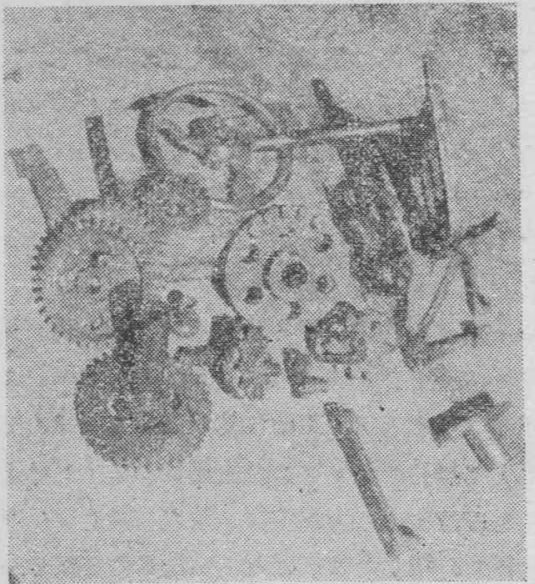

(第 2 困) 裝 置の部品

り2をバネ4のカに 抗して左に移動させ る。同時に 2 の外側 面は鼓形車 5 の切久 部より離れ 5 及びこ れと一体に作られた 変形莱事 6 の回轱引 自由にする。 2 の爪 Cは同封に変形歯率 に䠛み合い、これを 半回転させて後、2 はバネのカにて右方 に鄍り、外側面は 5 の切久部に括さまり

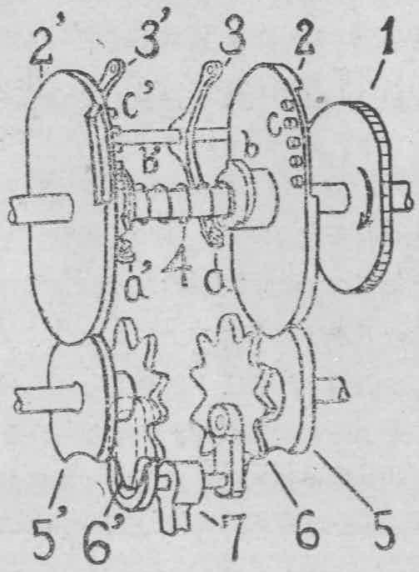

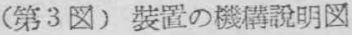

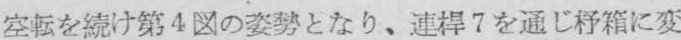
位を与える。

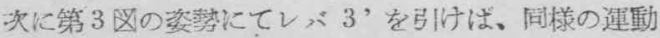
飞て第 5 図の姿势を取る。
第 5 区の姿樊よりレバ 3 を引くか或は第 3 汹より 3 及 び 3’を同時に引けば第 6 図の姿勢に变る。
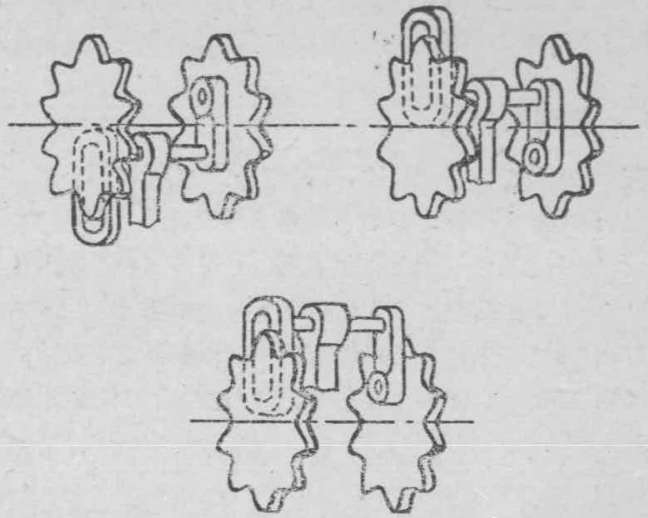

(第 4. 四)

(第 5 区)

(第 6 図)

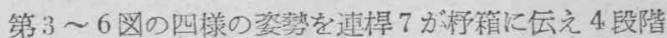
の変位を与える。徉つてレバ 3 及び 3 'の作動の組合せに て任意の 4 種の杼替を行い得る。レバの作動はドビー、ヂ ヤカード或はチェーンの何れを利用するる任澺である。

\section{3. 製作及び機能試驗の結果}

本装置は製作及び使用における費用並びに労力の節約 を目的とし、櫄力部品数を少くし工作の工程を省略した。 部品は取付ボルト等を除き18個

組立後の大さは $25 \times 25 \times 35 \mathrm{~cm}^{3}$

総電量は34.5 kg

工作は媔動部を旋盤加工し、他は総て鏬にて表面をな らす程度の墨皮のまらにて充分機能を発揮し得るよろに 精密部分を澼け、軸以外は総て鑵造により製作する。 本裝置を単独にて運転し、その消費動力の測定值は、 85 r. p. m. (織機は 170 r. p. m.)

$\begin{array}{ll}\text { 室転継続に恐する動力 } & 0.021 \mathbb{P} \\ \text { レバを引くに姴する仕事量 } & 80 \mathrm{grcm}\end{array}$

レバる引き裝置す作動するに要する動力の最大值
(1) レバ 1 個の時
0.029 IP
(2) レバ 2 佪の時 $0.034 \mathbb{P}$

本裝置を2 台試作実用試験を行つた結果 2 ケ月間に機 能上の故障は皆無であつた。

\section{4. 結、語}

1. 本装置は崝吅な部品を極力避け木熟者にも容易に 組六及び調整し得るようにした。

2. 動力及ひ沮油等の消費量は從来のすのK比し非常 に䬣約された。

3. 裝着に刘する特別の附属品を必要とせず、使用中 の織機に直にボルトにて取付使用し得る。 